\title{
Anticorrosive paint with a modified zeolite as functional pigment for SAE 1010 steel protection
}

\author{
Oriana D'Alessandro and Christian Eduardo Byrne \\ CIDEPINT, La Plata, Argentina and Faculty of Exact Sciences, Universidad Nacional de la Plata, La Plata, Argentina \\ Gonzalo Selmi \\ CIDEPINT, La Plata, Argentina, and \\ Cecilia Deyá \\ CIDEPINT, La Plata, Argentina and Faculty of Engineering, Universidad Nacional de la Plata, La Plata, Argentina
}

\begin{abstract}
Purpose - This paper aims to formulate and prepare a series of alkyd paints with new anticorrosive pigments, eco-friendly to the environment, based on a natural zeolitic rock modified by ion exchange to incorporate passivating cations.

Design/methodology/approach - The electrochemical characterization of the painted steel was carried out by conductivity measurements, linear polarization tests, measurements of the corrosion potential and electrochemical noise measurements. Besides, accelerated tests in standard environmental chambers were also carried out.

Findings - The results show that clinoptilolite-mordenite-based pigments incorporated in the paint provide acceptable anticorrosive properties, taking into account their low environmental impact and the use of a natural resource of low cost. The inhibitory efficiency of ZLa is higher than $80 \%$ and of ZPr is close to $70 \%$. The electrochemical assays of the coated panels with the alkyd paints ZLa and ZPr shows similar behavior.

Research limitations/implications - In this work, good results were obtained with an alkyd resin, but other resins could be tested. Paints could also be formulated with modified zeolites as a complement to others traditional anticorrosive pigments.

Practical implications - These paints could be used for the protection of metal structures in low corrosive environments.

Originality/value - There are not many published works using zeolites as anticorrosive pigments.
\end{abstract}

Keywords Zeolite, Lanthanum, Praseodymium, Alkyd paint

Paper type Research paper

\section{Introduction}

In the process of metallic corrosion, metals interact with their environment and begin to degrade electrochemically. The economic losses associated with this deterioration make it one of the most serious and challenging problems that have to face different productive sectors throughout the world. The most used preventive method for metal surfaces protection involves the application of anticorrosive coatings (Orman, 1965). Through this strategy, protection is achieved as the result of the barrier effect associated with the resin used and the inhibitory effect directly linked to the functional anti-corrosive pigment (Bierwagen and Huovinen, 2010).

The functional pigment is a solid material finely divided which is dispersed in the film-forming material. The selection of the functional pigment is intimately related to the field of

The current issue and full text archive of this journal is available on Emerald Insight at: https://www.emerald.com/insight/0369-9420.htm

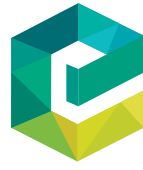

Pigment \& Resin Technology

(C) Emerald Publishing Limited [ISSN 0369-9420]

[DOI 10.1108/PRT-05-2020-0052] application of the paint, that is to say, to the surface that is desired to be protected in a given environment. It is necessary that the pigment be insoluble in the paint for remain its original physical chemistry properties. The protection mechanisms of the anticorrosive pigments involve, in general, the formation of an insoluble protective film or the supply of passive soluble ions. The anticorrosive pigments traditionally used for steel protection are red lead $\left(2 \mathrm{PbO} \mathrm{PbO}_{2}\right)$, chromates $\left(\mathrm{ZnCrO}_{4}\right.$, $\left.\mathrm{K}_{2} \mathrm{CrO}_{4} \cdot 3 \mathrm{ZnCrO} \cdot \mathrm{Zn}(\mathrm{OH})_{2}, \quad \mathrm{ZnCrO}_{4} \cdot 4 \mathrm{Zn}(\mathrm{OH})_{2}\right) \quad$ and phosphates. There are three generations of commercial phosphates, and zinc phosphate is their precursor and zinc molybdophosphate (ZMP) is one of the most important ones. The protection mechanisms can be described for each pigment: red lead (or minium) reacts with the acid groups of the resin and generates an organic salt that is deposited on the surface of the iron (Abel, 1999); chromates are part of the protective film

The authors thank to Consejo Nacional de Investigaciones Científicas y Técnicas (CONICET), Universidad Nacional de La Plata (UNLP) and Comisión de Investigaciones Científicas de la Provincia de Buenos Aires (CICPBA), for the financial support to do this research's.

Received 29 May 2020

Revised 11 July 2020

Accepted 19 July 2020 
in the anodic regions (McCafferty et al., 1988); phosphates promotes the formation of iron oxyhydroxides onto the steel surface, and its salts precipitate with high adherence over the cathode areas (Blustein et al., 2005).

These traditional pigments have proven to be very effective for corrosion protection in aggressive media, but the current trend is to stop using them because of their toxicity and environmental impact. Lead is considered a toxic compound that affects mainly the renal, reproductive and nervous systems (Ab Latif et al., 2015), hexavalent chromium causes a great variety of diseases from dermatitis to bronchial carcinomas depending on the type of interaction with this toxic chemical compound (Baruthio, 1992), and phosphates cause the increase of phosphorus supplies in aquatic ecosystems promoting the abundance of algae and aquatic plants, degrading water resources by eutrophication (Nasir Khan and Mohammad, 2014). This new perspective gave rise to a great variety of new research on the use of alternative inhibitory pigments, among them, are the modified zeolites. However, these alternatives protect the metal substrate in selective environment, and they must be chosen carefully to have the better possible protection.

Zeolites are metamorphic minerals, rocks formed from other preexisting in the depths of the earth's crust as a result of variations in temperature, pressure and shear stresses (Klein and Philpotts, 2017). This material is hydrated aluminosilicates of alkaline and alkaline-earth metals, with a three-dimensional structure consisting of a network of $\mathrm{AlO}_{4}$ and $\mathrm{SiO}_{4}$ tetrahedra linked by the $\mathrm{O}$ atoms of their vertex (Devaki and Gomathi Priya, 2016). This structure is characterized by the presence of cavities and intercommunicated channels, usually occupied by water molecules and interchangeable extra-reticular cations (Calabrese, 2018). Its properties of high surface area, elevated cation exchange capacity and acidity justify the wide use of zeolites as adsorbents, catalysts, ion exchange agents, antimicrobials (Al-subaie et al., 2015; Rojas-Pavón et al., 2015; Kozhevnikova and Styazhkina, 2013; Stashkiv et al., 2019; Alshameri et al., 2019; Kustovska, 2018; Iyigundogdu et al., 2014; Kabwadza-Corner et al., 2014) and, in our case, as containers that allow a gradual release of corrosion-inhibiting ions (Ahmed et al., 2011; Dias et al., 2012; Ferrer et al., 2014; Shaw and Tiwari, 2016; Dias et al., 2014; Roselli et al., 2014; Roselli et al., 2018; Abd El-Gawad et al., 2019).

Among the natural zeolites clinoptilolite and mordenite are remarkable for their low cost, quantity and availability (Armbruster, 2001). Clinoptilolite is a member of the heulandite group, has a similar structure (framework type $\mathrm{HEU}$ ), and differs from it in the $\mathrm{Si} / \mathrm{Al}$ ratio (less than 4 for heulandite, and between 4 and 5.2 for clinoptilolite) (Mansouri et al., 2013). Mordenite belongs to another structural group (framework type MOR) with $\mathrm{Si} / \mathrm{Al}$ ratio between 4.5 and 5 (Munthali et al., 2014; Baerlocher et al., 2007).

This article presents the study of the anticorrosive behavior of two alkyd paints formulated with a modified zeolitic rock for SAE 1010 steel protection. Natural zeolite was exchanged with cations $\operatorname{Pr}(\mathrm{III})$ in one case and $\mathrm{La}(\mathrm{III})$ in another, both of them with known inhibitory capacity in solution and now retained in the zeolite (D'Alessandro et al., 2019). The performance of these new paints is compared to a paint containing the traditional ZMP as anticorrosive pigment.

\section{Experimental}

\section{Materials}

A natural zeolitic rock from the deposit of San Andrés (Cuba), which consists in a mixture of mordenite and clinoptiloliteheulandite was used (Brito-Rojas et al., 2017; Selvam et al., 2018).

\section{Method for the preparation of the modified zeolites}

The natural zeolite was crushed in mortar to obtain a fine powder with an average particle size $<10 \mu \mathrm{m}$. Then it was washed twice with distilled water by mechanical stirring; the suspension was allowed to stand overnight and the solid was separated by centrifugation at $2200 \mathrm{rpm}$. To remove the ferric compounds, the zeolite was in contact with a $0.2 \mathrm{M} \mathrm{HNO}_{3}$ at boiling temperature for $1 \mathrm{~h}$, then the material was separated by centrifugation and washed with distilled water three times.

The determination of the cation exchange capacity of the pre-treated zeolitic rock was carried out by saturating the exchange sites with $\mathrm{K}^{+}$from $1 \mathrm{M} \mathrm{KCl}$ solution under continuously stirring. Then, the solid was separated by centrifugation, washed three times with distilled water and dried in an oven until constant weight. Finally, the zeolite was placed in a beaker and contacted with $1 \mathrm{M} \mathrm{NH} \mathrm{NH}_{4} \mathrm{Cl}$ under continuously stirring, replacing the $\mathrm{K}^{+}$with $\mathrm{NH}_{4}{ }^{+}$, and the released $\mathrm{K}+$ was determined by atomic adsorption (Shimadzu AA7000).

To convert the zeolite into its sodium form $(\mathrm{ZNa})$, a suspension of the pre-treated zeolite with a $2 \mathrm{M} \mathrm{NaCH}_{3} \mathrm{COO}$ solution was under continuously stirring for $3 \mathrm{~h}$. Then $\mathrm{ZNa}$ was separated by centrifugation and washed twice with distilled water.

The characterization of the $\mathrm{ZNa}$ material was carried out by Infrared Spectroscopy with Fourier Transform (FTIR) and X ray Diffraction (XRD) with Perkin Elmer Spectrum ONE FTIR spectrometer, spectral range $4000-450 \mathrm{~cm}^{-1}$, resolution $4.00 \mathrm{~cm}^{-1}, 10$ scans and Philips-APD PW 1710, radiation source $\operatorname{CuK} \alpha$ at $1,542 \AA$ with nickel filter and angular range $5^{\circ}-70^{\circ}$, respectively.

Finally, to obtain the modified zeolites, two portions of $\mathrm{ZNa}$ were exchanged with rare earth metal cations. One portion was exchanged with $\mathrm{La}(\mathrm{III})$ from $\mathrm{La}\left(\mathrm{NO}_{3}\right)_{3} 0.1 \mathrm{M}$ solution and the other one with $\operatorname{Pr}(\mathrm{III})$ from $\operatorname{Pr}\left(\mathrm{NO}_{3}\right)_{3} \mathrm{O} .1 \mathrm{M}$. Both suspensions were stirring at $300 \mathrm{rpm}$ for $24 \mathrm{~h}$ to carry out the ion exchange. The minerals exchanged were separated by centrifugation, washed four times with distilled water and dried at $90^{\circ} \mathrm{C}$ until constant weight (Ming and Dixon, 1987). The exchanged zeolites were designated ZLa for the case where the exchanged cation is $\mathrm{La}(\mathrm{III})$ and $\mathrm{ZPr}$ when $\operatorname{Pr}(\mathrm{III})$ is the exchanged cation.

Method for the characterization of the modified zeolites The anticorrosive performance of the modified zeolites (ZLa, $\mathrm{ZPr}$ and $\mathrm{ZNa}$ ) was evaluated by electrochemical techniques.

Corrosion potential and analysis of the surface

SAE 1010 steel electrodes of $1 \mathrm{~cm}^{2}$ of exposed area were immersed in suspensions of the pigments with $0.1 \mathrm{M} \mathrm{NaCl}$ and the corrosion potential (Ecorr) was recorded as a function of exposure time for $4 \mathrm{~h}$, using a saturated calomel electrode (SCE) as reference electrode. The Ecorr of steel electrodes in $0.1 \mathrm{M} \mathrm{NaCl}$ solution without pigments was also measured. 
Oriana D'Alessandro et al.

SAE 1010 steel panels of $1.0 \mathrm{~cm}^{2}$ of exposed area were immersed for $24 \mathrm{~h}$ in the ZLa, ZPr suspensions and in the $0.1 \mathrm{M} \mathrm{NaCl}$ solution. Then they were washed with distilled water and dried with a tissue paper for the analysis by scanning electron microscopy (SEM). Also, the elemental composition of the surface was obtained by X-ray scattering spectroscopy (EDXS). The equipment used was a FEI Microscope, Quanta 200 model and an energy dispersive micro analyzer with EDAX Apollo 40 detector.

\section{Linear polarization resistance}

The polarization resistances in the aforementioned suspensions, after 2,5 and $24 \mathrm{~h}$ of immersion were also evaluated. In these cases, an electrochemical cell consisting in a SAE 1010 steel electrode of $0.28 \mathrm{~cm}^{2}$ of exposed area as working electrode, a platinum counter electrode and an SCE as reference electrode was used. A range of $\pm 20 \mathrm{mV}$ respect the open circuit potential with a scan rate of $0.25 \mathrm{mV} \cdot \mathrm{s}^{-1}$ were selected as measurements conditions using a potentiostat/ galvanostat Gamry Interface 1000. All measurements were made in duplicate. The reference test was carried out without pigment (blank test).

The inhibitory efficiency was calculated from the equation:

$$
\mathrm{IE} \%=\frac{\mathrm{Rp}-\mathrm{Rp}_{0}}{\mathrm{Rp}} * 100
$$

where $\mathrm{Rp}$ is the polarization resistance in presence of the anticorrosive pigment and $\mathrm{Rp}_{0}$ is the polarization resistance obtained in the blank test (Saxena et al., 2020).

\section{Method for the formulation, preparation and application of paints}

The anticorrosive paints were prepared taking into account a typical formulation (Brito-Rojas et al., 2017) replacing, in volume, the anticorrosive pigment by the pigments $\mathrm{ZLa}$ and ZPr (Table 1).

All the components were weighed to an accuracy of $0.1 \mathrm{~g}$, and the paints were prepared in a Hulman Hnos. Srl ball mill dispersing at $70 \mathrm{rpm}$ for $24 \mathrm{~h}$. The preparation of the surface was carried out by sandblasting the metallic substrate until reaching a total roughness of $25 \pm 2 \mu \mathrm{m}$, determined with a Hommel Tester LV15 rugosimeter. The panels were degreased with toluene. The application of the paint was done with a brush. The total thickness of the dry film obtained after two applications was $80 \pm 5 \mu \mathrm{m}$, determined with the thickness gauge Schwyz SC117-02 Coating Thickness Gauge.

Table 1 Composition of the anticorrosive paint

\begin{tabular}{llr}
\hline Components & Function & $\% \mathrm{v} / \mathrm{v}$ \\
\hline Main pigment & Anticorrosive pigment & 6.54 \\
Magnesium silicate & Filler & 6.37 \\
Barite & Filler & 6.20 \\
Titanium dioxide & Prime pigment & 2.55 \\
ALKIPOL 434/50 & Film forming material & 60.23 \\
White spirit & Solvent & 18.11 \\
Total & & 100.00 \\
\hline
\end{tabular}

\section{Method for the evaluation of coatings}

\section{Accelerated tests in salt spray chamber and humidity} chamber

A set of three coated panels was placed for 15 days in the salt spray chamber (ASTM B 117) to evaluate the rusting degree (ASTM D 610). A similar set was placed for 15 days in the humidity chamber (ASTM D 2247) for blistering assessment (ASTM D, 714).

\section{Linear polarization resistance and conductivity measurements}

The electrochemical tests were carried out in a cell constructed by delimiting on the painted surface a circular area of $3 \mathrm{~cm}^{2}$ by means of a polyvinyl chloride (PVC) tube adhered with an epoxy-type glue and then sealed with beewax on the outside of the tube. Finally, a defined volume of $0.1 \mathrm{M} \mathrm{NaCl}$ was added. The ionic resistance $(\mathrm{Ri})$ between the painted steel substrate and a platinum electrode was determined by conductivity measurements using an Orion Model 170 ATI at $1000 \mathrm{~Hz}$. The polarization resistance (Rp) were determinate with a Gamry Interface 1000 potentiostat, in a range of $\pm 20 \mathrm{mV}$ respect to open circuit potential with a scan rate of $1 \mathrm{mV} / \mathrm{s}$. A Pt ring electrode was used as the counter electrode and the reference electrode was the SCE. To measure the corrosion potential, the SCE was used as a reference. All measurements were made in quadruplicate.

\section{Electrochemical noise measurements}

The cell for electrochemical noise measurements was constituted by two identical nominal painted panels and the SCE as reference. The exposed area, delimited with beewax, was $50 \mathrm{~cm}^{2}$. The three electrodes were dipped into a $0.5 \mathrm{M}$ $\mathrm{NaCl}$ solution and the potential and the current noise were simultaneously recorded until blisters appeared on the painted panels using the Gamry Interface 1000 potentiostat. The sensitivity of the measuring device in the E-scale was $0.01 \mathrm{mV}$ and $0.1 \mathrm{nA}$ in the current measurements. Each time series contained 4,000 points. DC trend was removed using the moving average removal method (Ashassi-Sorkhabi et al., 2016) before any analysis. The results were studied in time domain to calculate the noise resistance $(\mathrm{Rn})$ as:

$$
\mathrm{Rn}=\sigma_{\mathrm{E}} / \sigma \mathrm{J}(\text { Jamali and Mills, 2016) }
$$

Rn was associated with the polarization resistance (Deyá et al., 2013), or the diffusion barrier properties (Hernández et al., 2009) by several authors.

\section{Results and discussion}

\section{Preparation of the modified zeolites}

The cation exchange capacity of the zeolitic rock was $1,335 \mathrm{mmol} / \mathrm{kg}$, a value close to that was reported in literature (Roselli et al., 2018).

The XRD pattern of the $\mathrm{ZNa}$ material showed maximums at $2 \theta=9.86 ; 22.42 ; 26.5 ; 11.16 ; 17.16$ and 29.84 (Figure 1). According to the database of Join Committee for Powder Diffraction Sources, these peaks correspond to a mixture of clinoptilolite (JCPDF \# 25-1349) and mordenite (JCPDF \# 29-1257). In addition, there are peaks of very low intensity associated with Silicon dioxide (JCPDF \# 44-1394). 
The FTIR spectrum of the ZNa material (Figure 2) showed water absorption bands between $1600-1700 \mathrm{~cm}^{-1}$ and between $3100-3500 \mathrm{~cm}^{-1}$ indicating that the zeolite is significantly hydrated. These bands, which were centered at 3455 and $1644 \mathrm{~cm}^{-1}$, are associated with tensile and bending movements of $\mathrm{O}-\mathrm{H}$. The band located at $1053 \mathrm{~cm}^{-1}$ corresponds to the vibration modes of asymmetric stretching of the internal TO bonds in $\mathrm{TO}_{4}$ tetrahedra ( $\mathrm{T}=\mathrm{Si}$ and $\left.\mathrm{Al}\right)$, while the external

Figure 1 XRD pattern of the pre-treated zeolite ZNa

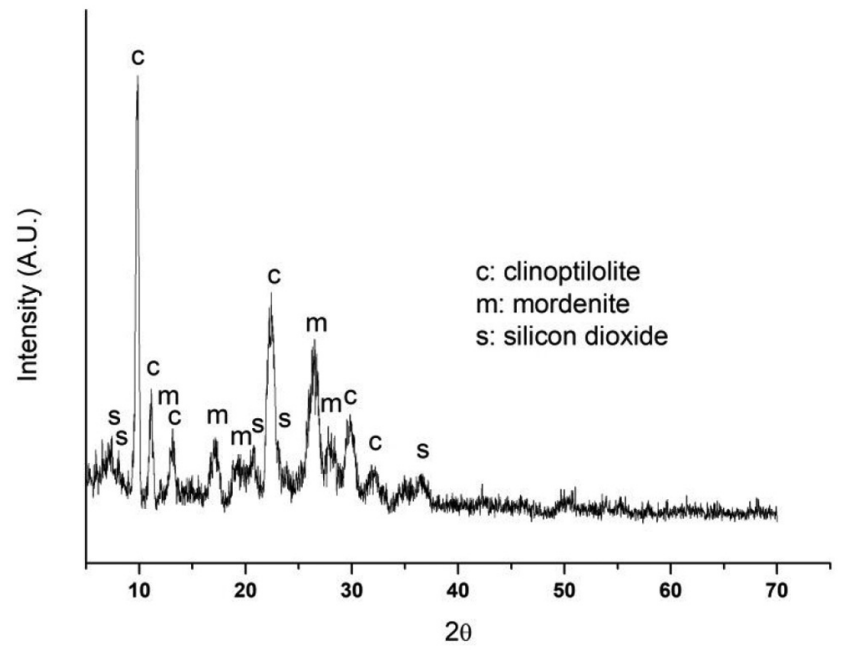

Figure 2 FTIR spectra of the pre-treated zeolite ZNa

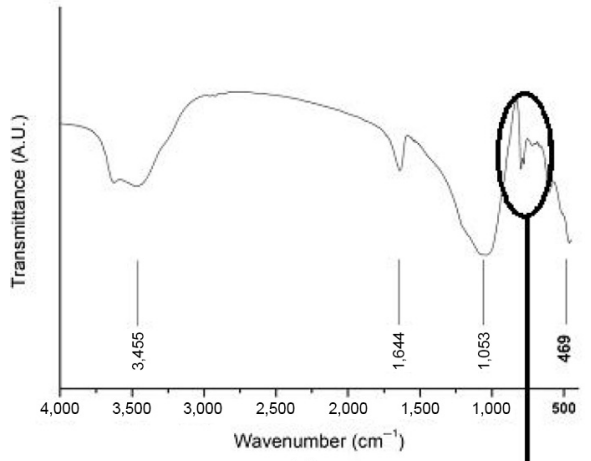

(a)

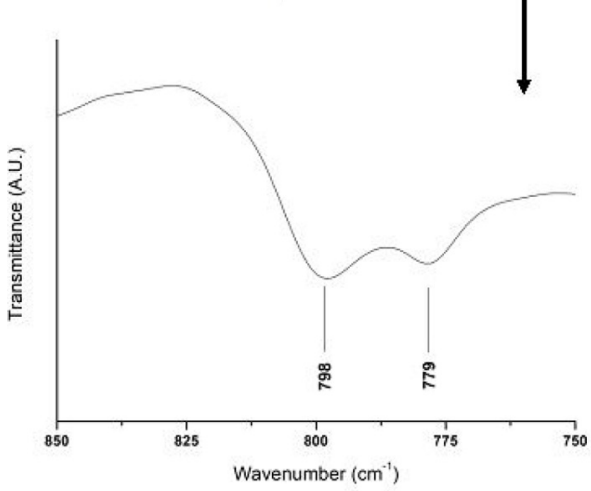

(b) vibrations associated with the links between tetrahedra appear in the range $650-900 \mathrm{~cm}^{-1}$. The 779 and $798 \mathrm{~cm}^{-1}$ bands are assigned to the stretching vibration modes of the O-T-O groups, while the vibrations at $469 \mathrm{~cm}^{-1}$ are associated with flexion movements of the O-T-O bonds (Munthali et al., 2014).

\section{Characterizations of the modified zeolites}

Corrosion potential and analysis of the surface

The corrosion potentials of the SAE 1010 steel in contact with the pigments suspensions (Figure 3 ) reveal that the zeolitic materials exchanged ZLa and ZPr exhibit a very similar behavior during the first $120 \mathrm{~min}$ and then both curves overlap, showing an identical behavior. During the $240 \mathrm{~min}$ of testing, both materials shift the corrosion potential toward more positive values with respect to the SAE 1010 steel, reaching a maximum displacement of $120 \mathrm{mV}$ after $240 \mathrm{~min}$ of testing. The pre-treated zeolite slightly modified the corrosion potential of the steel $(50 \mathrm{mV}$ maximum). During the first $180 \mathrm{~min}$, it shifts the potential toward positive values and then towards negative values with respect to the blank test.

The SEM study of the SAE 1010 specimens in contact with the pigment suspensions reveals a substantial difference between the materials exchanged and the pre-treated zeolite. The materials $\mathrm{ZLa}$ and $\mathrm{ZPr}$ are retained in the formed protective film, but there is no evidence of the material $\mathrm{ZNa}$ on the surface of the SAE 1010 steel.

In all, microphotographs can be distinguished the roughness of the sanded surface.

In the photo of ZLa as in that of $\mathrm{ZPr}$ two regions can be distinguished, one is a homogeneous thin film (A) and the other are mineral particles (B). Also, the spectra for both regions are presented (Figure 4).

The EDS quantification of the ZLa and ZPr samples in the A region evidences the presence of the zeolite, since $\mathrm{Si}$ and $\mathrm{Al}$ appear in appreciable amounts which is in agreement with the

Figure 3 Ecorr vs SCE of steel immersed in the suspensions and the blank test

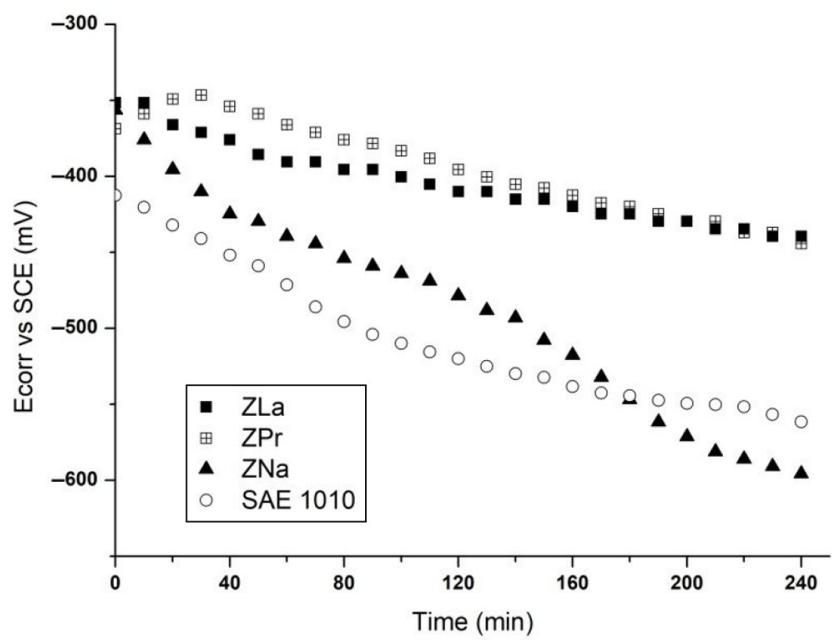


Figure 4 500x micrographs of the SAE 1010 specimens in $0.1 \mathrm{M} \mathrm{NaCl}$ and in contact with the ZLa, ZPr and ZNa suspensions

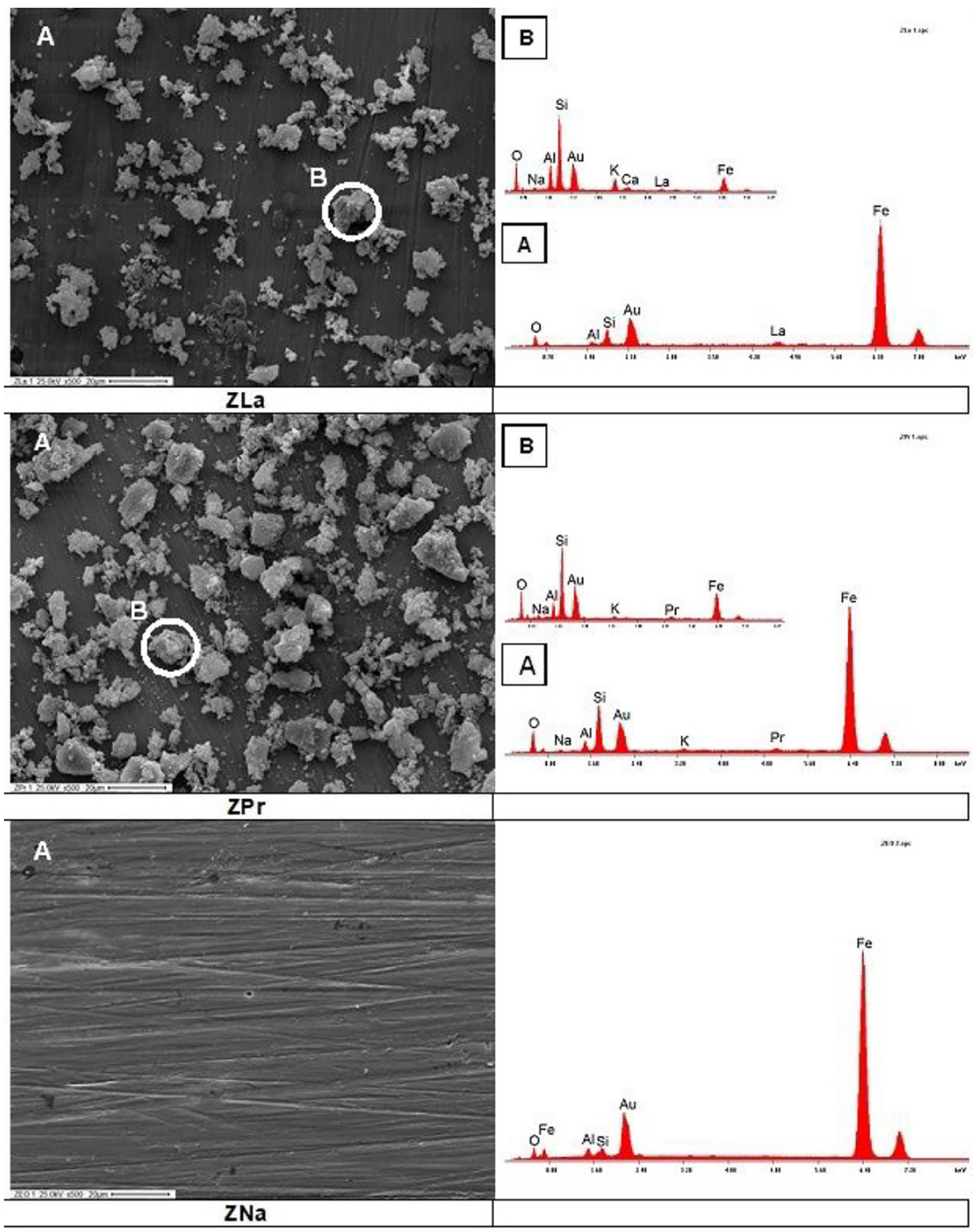

microphotography, while for $\mathrm{ZNa}$ the presence of $\mathrm{Al}$ and $\mathrm{Si}$ is scarce (Table 2).

The analysis of the $\mathrm{B}$ region demonstrates the presence of alkaline metals, characteristic of the structure of the mineral, as well as the presence of the passivating cations in each case.

\section{Linear polarization resistance}

The Rp values (Table 3) allow establishing that the polarization resistance provided by the pigment $\mathrm{ZLa}$ is greater than that given by the pigment ZPr. In terms of the percentage of inhibition it is possible to say that the material that releases the inhibitory cation $\mathrm{La}(\mathrm{III})$ causes an inhibition higher than $80 \%$ while the one that releases $\operatorname{Pr}(\mathrm{III})$ reaches an efficiency of inhibition higher than $70 \%$. On the other hand, the pre-treated
Table 2 EDS Quantification of the SAE 1010 samples in $0.1 \mathrm{M} \mathrm{NaCl}$ and in contact with the ZLa, ZPr and ZNa suspensions

\begin{tabular}{|c|c|c|c|c|c|}
\hline \multirow{2}{*}{$\begin{array}{l}\% \text { w/w } \\
\text { Region }\end{array}$} & \multicolumn{2}{|c|}{ ZLa } & \multicolumn{2}{|c|}{$\mathrm{ZPr}$} & \multirow{2}{*}{$\begin{array}{c}\mathrm{ZNa} \\
\mathrm{A}\end{array}$} \\
\hline & $A$ & B & A & B & \\
\hline $\mathrm{Fe}$ & 73.76 & 9.57 & 57.99 & 18.62 & 85.57 \\
\hline 0 & 8.78 & 34.48 & 12.84 & 30.72 & 5.33 \\
\hline Si & 10.83 & 35.34 & 19.15 & 35.95 & 4.31 \\
\hline Al & 3.03 & 10.99 & 5.11 & 7.71 & 4.79 \\
\hline $\mathrm{Na}$ & - & 1.77 & 2.49 & 2.71 & - \\
\hline K & - & 4.51 & 0.52 & 0.98 & - \\
\hline $\mathrm{Ca}$ & - & 1.26 & - & - & - \\
\hline La & 3.60 & 2.08 & - & - & - \\
\hline $\operatorname{Pr}$ & - & - & 1.90 & 3.31 & - \\
\hline Total & 100.00 & 100.00 & 100.00 & 100.00 & 100.00 \\
\hline
\end{tabular}


Table 3 Rp of Steel immersed in the pigment suspensions

\begin{tabular}{lccr}
\hline Pigment & 2h & Rp $\left(\mathbf{o h m} \times \mathrm{cm}^{2}\right)$ & \\
\hline ZLa & 1043.42 & 1526.56 & 24h \\
ZPr & 745.50 & 751.52 & 1693.30 \\
ZNa & 122.19 & 254.87 & 1048.88 \\
SAE 1010 & 172.80 & 193.20 & 333.34 \\
\hline
\end{tabular}

material $(\mathrm{ZNa})$, after $2 \mathrm{~h}$ of testing, increases the corrosion rate of the SAE 1010 steel, evidenced by a decrease of almost $30 \%$ in the polarization resistance at the other times tested. The inhibition efficiency barely reaches $25 \%$.

\section{Evaluation of coatings}

Accelerated tests in salt spray chamber and humidity chamber

The accelerated tests indicate, Table 4 that after 15 days of exposure, in the salt spray chamber the sample with ZMP presents the best possible rating while $\mathrm{ZPr}$ and $\mathrm{ZLa}$ have a medium score. In humidity chamber the sample containing ZMP presents a higher score than the ZPr and ZLa samples.

\section{Linear polarization resistance and conductivity} measurements

The study of Ionic resistance as a function of time reveals that paints with ZPr and ZLa have a low barrier effect that is lost after two days of testing while the paint containing ZMP shows an acceptable barrier effect during the first 12 days of testing (Figure 5).

The analysis of $\mathrm{Rp}$, as shown inFigure 6, over time reveals that the panels coated with the paints containing $\mathrm{ZPr}$ and $\mathrm{ZLa}$ reach a value below the acceptable one after 2 days of testing, while for the painting with ZMP the performance is acceptable for 15 days.

In Figure 7, it can be seen that samples containing $\mathrm{La}(\mathrm{III})$ and $\mathrm{Pr}$ (III) reached the Ecorr of bare steel $(-650 \mathrm{mV})$ after 100 days of testing while the sample with $\mathrm{ZMP}$ Ecorr is maintained after 40 days of testing at a value of $-500 \mathrm{mV}$.
Figure 5 lonic resistance (Ri) of the painted panels as a function of time

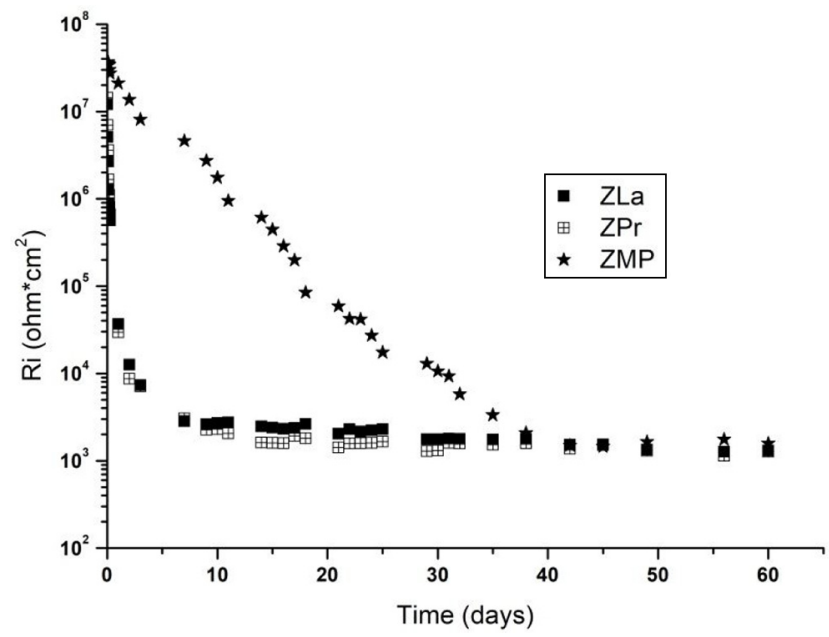

Figure 6 Polarization resistance (Rp) of the painted panels as a function of time

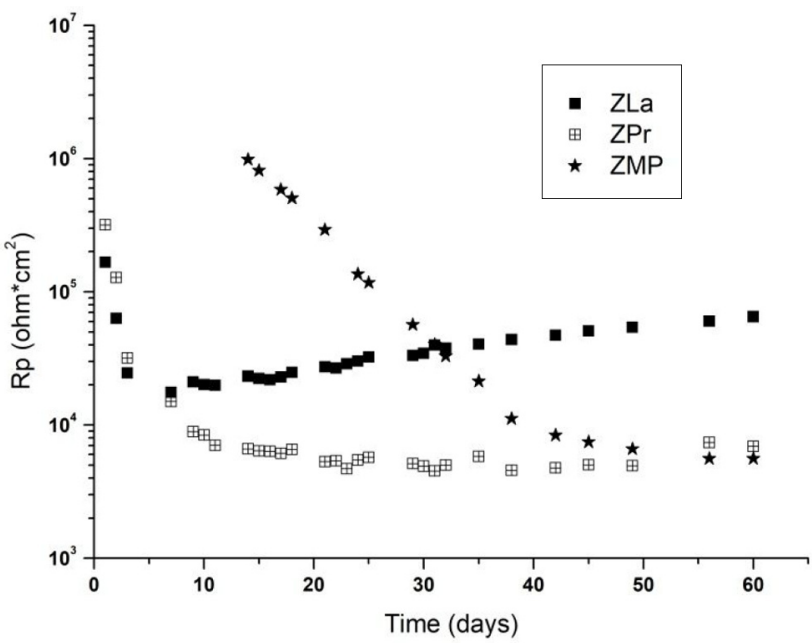

\section{Electrochemical noise measurements}

When the noise spectra of corrosion potential and coupling current are analyzed (Figures 8-10), important differences can be seen in the behavior of the painted panels.

Table 4 Corrosion and blistering degrees of the painted panels exposed in salt spray chamber and humidity chamber

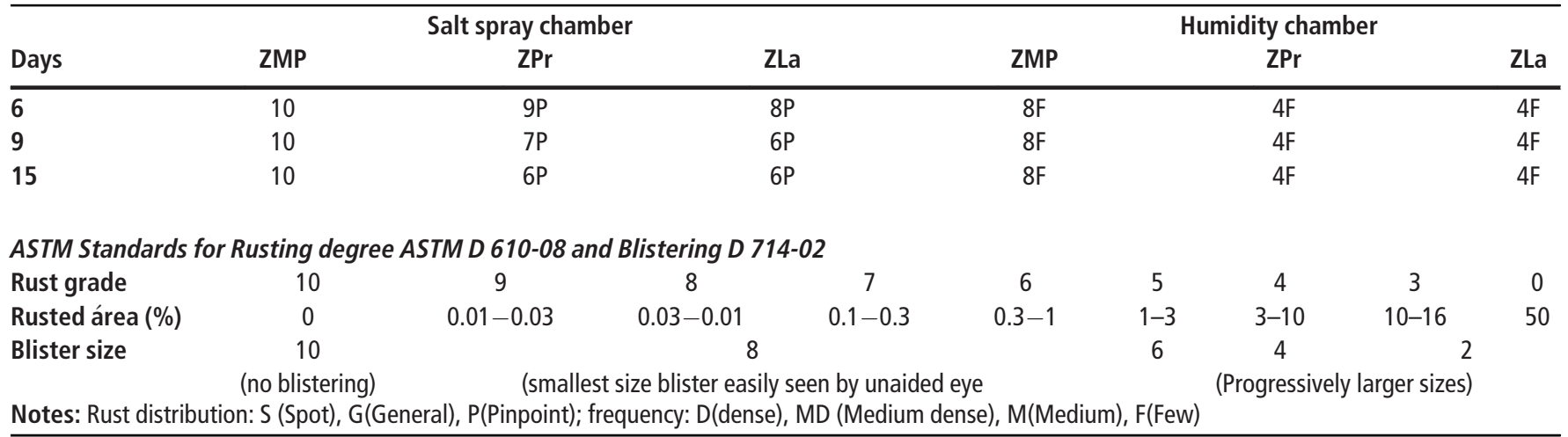


Figure 7 Corrosion potential (Ecorr) vs. SCE of the painted panels as a function of time

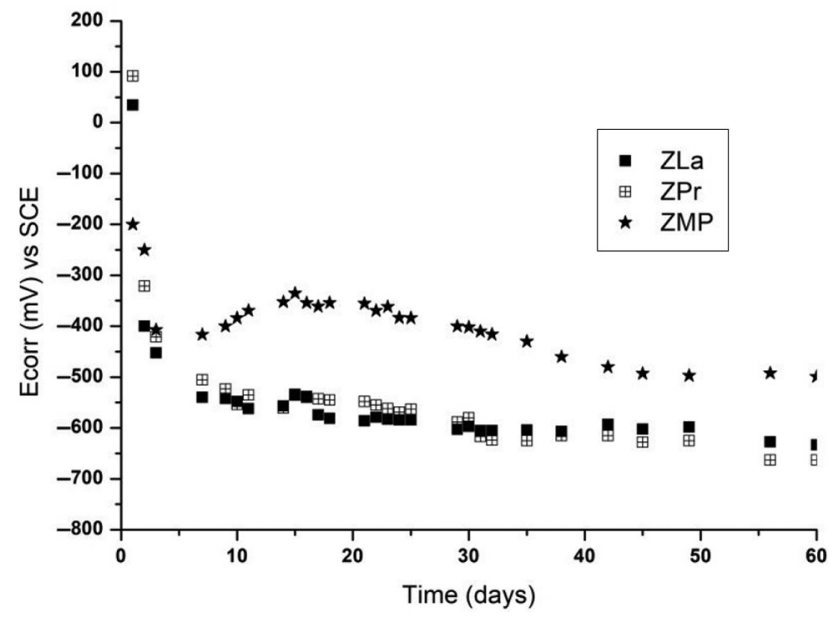

Figure 8 Noise spectra of ZLa samples after immersion for (a) $10 \mathrm{~h}$, (b) $40 \mathrm{~h} \mathrm{(c)} 70 \mathrm{~h}$; before removing
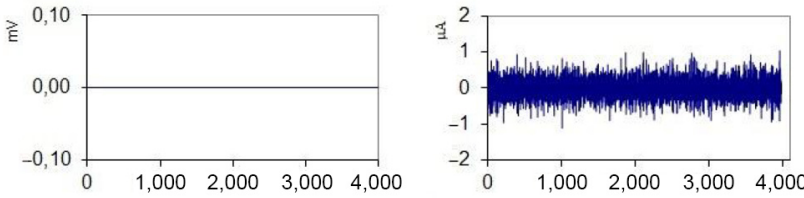

(a)
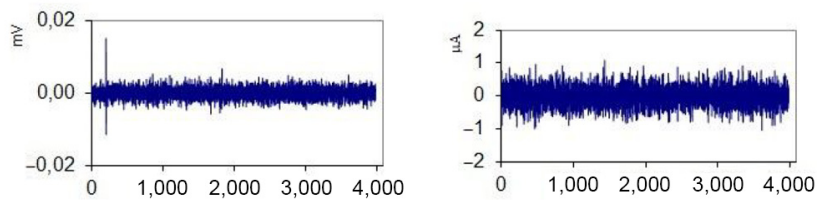

(b)
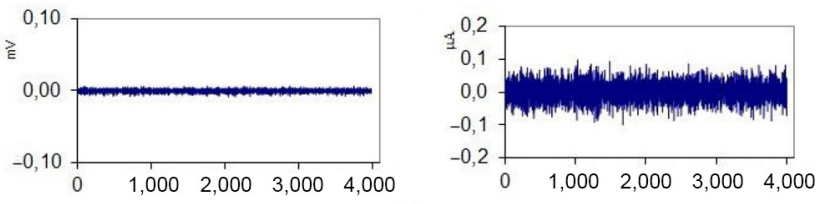

(c)
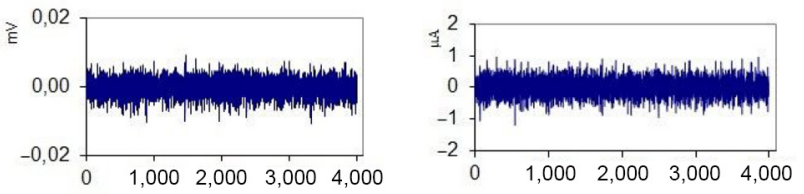

(d)

During the immersion time, ZLa sample showed no transients in the potential nor in the current spectra but in this last case, the noise is in the order of $\mu \mathrm{A}$ (Figure 8). The potential spectra showed very little noise, around $0.01 \mathrm{mV}$, closed to the sensitivity of the equipment [Figure 8(a)]. In the case of ZPr samples, some transients appeared in the potential spectra after 10,70 and at the end of the tests, being more intense as the time elapsed [Figure 9(a)]. These spectra are characteristics of a mixed (local and generalized) attack over the surface (Hernández et al., 2009). After 40 hours of immersion only noise appeared in the potential spectra. When the current spectra are analyzed, the behavior is similar to ZLa samples. The important oscillations in the corrosion potential values will results in high values of $\mathrm{Rn}$ (Figure 9).

The ZMP painted panels showed transients in the corrosion spectra after $10 \mathrm{~h}$ of immersion and after $70 \mathrm{~h}$, the transients are superimposed to noisy signals indicating mixed attack. After $40 \mathrm{~h}$ and before removing the panels from the electrolyte, the spectra showed only noisy signals (Figure 10). The little amplitude of the potential noise would explain the low $\mathrm{Rn}$ values. The current spectra showed mostly noise signals along the test. The current noisy signals are associated with propagation events (Hernández et al., 2009).

The evolution of Rn along time can be seen in Figure 11. These values showed important oscillations during the first $55 \mathrm{~h}$ of immersion in the cases of samples ZLa and ZPr. However, in the case of $\mathrm{ZLa}$, the general trend is to diminish $\mathrm{Rn}$ up to values around $400 \Omega . \mathrm{cm}^{2}$, value that was kept constant until the end of the assay. The low values of $\mathrm{Rn}$ are because of the small oscillation in the corrosion potential during measurements, while the oscillations can be associated to cycles of blocking - opening pores of the coating due to accumulation - removal of corrosion products. On the other

Figure 9 Noise spectra of ZPr samples after immersion for (a) $10 \mathrm{~h}$, (b) $40 \mathrm{~h}$ (c) $70 \mathrm{~h}$; before removing
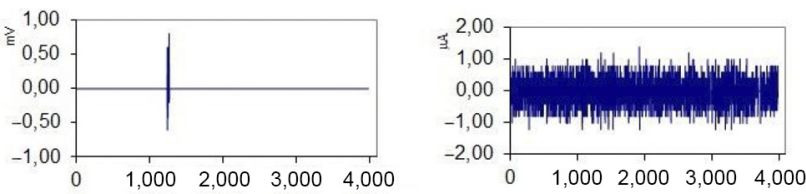

(a)
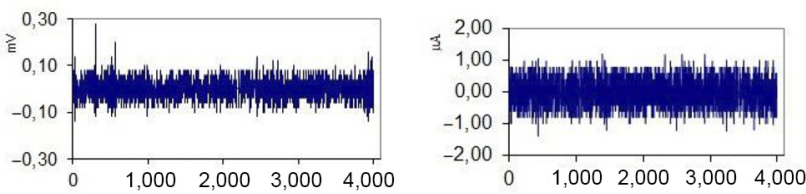

(b)
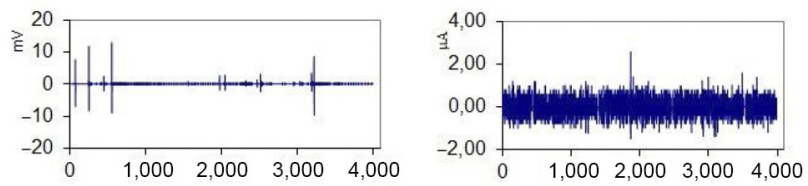

(c)
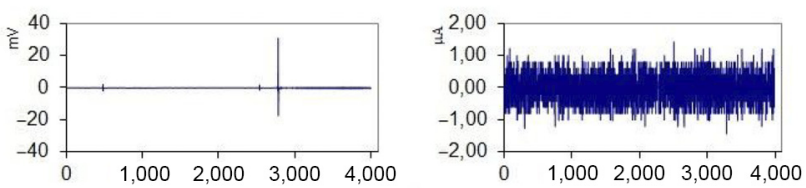

(d) 
Figure 10 Noise spectra of ZMP samples after immersion for (a) $10 \mathrm{~h}$, (b) $40 \mathrm{~h} \mathrm{(c)} 70 \mathrm{~h}$; before removing
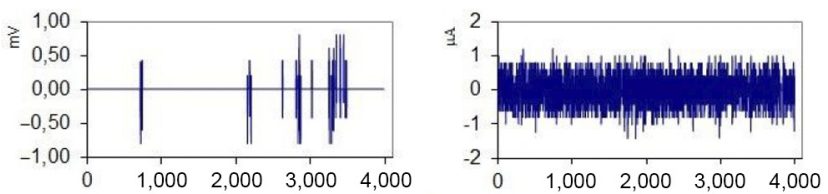

(a)
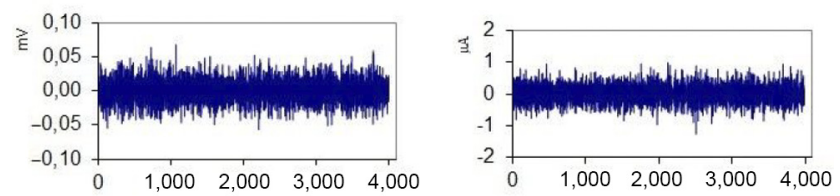

(b)
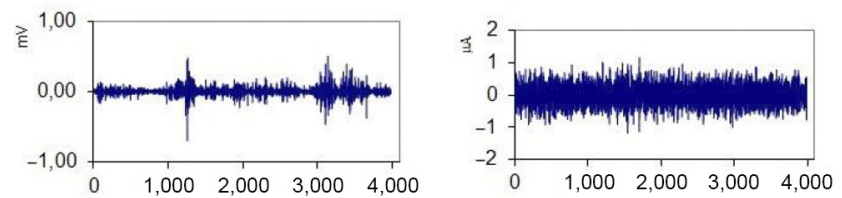

(c)
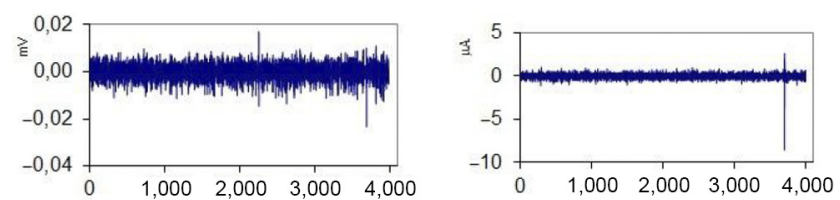

(d)

Figure 11 Electrochemical noise resistance $(\mathrm{Rn})$ of the painted panels

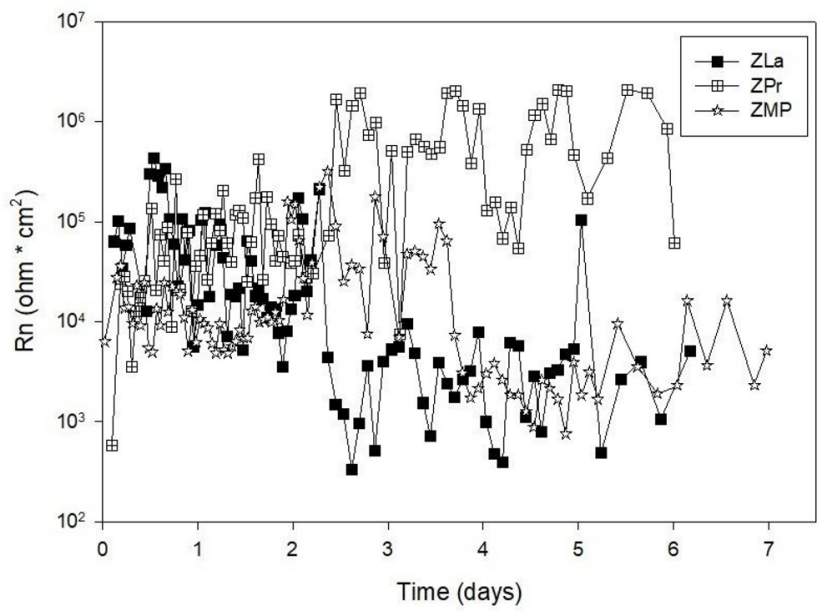

hand, in the case of $\mathrm{ZPr}, \mathrm{Rn}$ values increased up to $6.10^{4} \Omega$. $\mathrm{cm}^{2}$ after 59 days and oscillations also increased being almost one order of magnitude until $144 \mathrm{~h}$, when the panels were removed from the electrolyte. The unexpected high value of $\mathrm{Rn}$ for $\mathrm{ZPr}$ samples showed the complex mechanism of the corrosion process. In the case of panels coated with ZMP paint, important oscillations started after 55 days, reaching values around $10^{4} \Omega . \mathrm{cm}^{2}$. After 88 days, Rn values decreased one order of magnitude and were constant until the end of the test.

\section{Conclusions}

It is possible to incorporate $\mathrm{La}$ (III) and $\operatorname{Pr}$ (III) cations into a natural zeolite and prepare an anticorrosive alkyd paint with the modified zeolites as functional pigments. The new paints presented a similar behavior in the salt spray chamber and in the humidity chamber and could be used in less aggressive environments considering that with these new pigments, the effects of eutrophication of aquatic ecosystems are avoided. Corrosion potential and ionic and polarization resistances determinations indicate a better behavior for the painting with ZMP than the paintings with ZLa and ZPr, while noise measurements showed the complex of the corrosion process.

\section{References}

Ab Latif, W., Anjum, A. and Jawed Ahmad, U. (2015), "Lead toxicity: a review", Interdisciplinary Toxicology, Vol. 8 No. 2, pp. 55-64.

Abd El-Gawad, W.M., Ahmed, N.M., Selim, M.M., Hamed, E. and Souaya, E.R. (2019), "The anticorrosive performance of cost saving zeolites", Pigment $\mathcal{E}$ Resin Technology, Vol. 48 No. 4, pp. 317-328.

Abel, A.G. (1999), "Pigments for paint", in Lambourne, R. and Strivens, T.A. (Eds), Paint and Surface Coatings, Woodhead Publishing Cambridge.

Ahmed, N.M., Emira, H.S. and Selim, M.M. (2011), "Anticorrosive performance of ion-exchange zeolites in alkyd-based paints", Pigment \& Resin Technology, Vol. 40 No. 2, pp. 91-99.

Al-Subaie, M.S.M., Al-Turkustani, A.M.A., Selvin, R. and AlMhayawi, S.R. (2015), "Anticorrosion nanocrystalline beta zeolite thin film for advanced applications", Fournal of Chemistry, Vol. 2015, p. 1-5.

Alshameri, A., Xinghu, W., Dawood, A., Assabri, A., Xin, C. and Yan, C. (2019), "Characterization of Yemeni natural zeolite (Al-Ahyuq area) and its environment applications: a review", Fournal of Ecological Engineering, Vol. 20 No. 4, pp. 157-166.

Armbruster, T. (2001), "Mesoporous materials at the dawn of the 21 st century", in Galarnau, A., Di Renzo, F., Faujula, F. and Vedrine, J. (Eds), 13 International Zeolite Conference, Elsevier. Montpellier.

Ashassi-Sorkhabi, H., Seifzadeh, D. and Raghibi-Boroujeni, M. (2016), "Analysis of electrochemical noise data in both time and frequency domains to evaluate the effect of $\mathrm{ZnO}$ nanopowder addition on the corrosion protection performance of epoxy coatings", Arabian fournal of Chemistry, Vol. 9, pp. S1320-S27.

Baerlocher, C., Mccusker, L.B. and Olson, D.H. (2007), "MOR - Cmcm", in Baerlocher, C., Mccusker, L.B. and Olson, D.H. (Eds), Atlas of Zeolite Framework Types, Elsevier Science B.V. Amsterdam.

Baruthio, F. (1992), "Toxic effects of chromium and its compounds", Biological Trace Element Research, Vol. 32 Nos 1/3, pp. 145-153. 
Bierwagen, G.P. and Huovinen, A.M. (2010), "Paint formulation", in Cottis, R.A., Graham, M.J., Lindsay, R., Lyon, S.B., Richardson, J.A., Scantlebury, J.D. and Stott, F. H. (Eds), Comprehensive Corrosion, Elsevier Science Amsterdam.

Blustein, G., Deyá, M.C., Romagnoli, R. and Amo, B.D. (2005), "Three generations of inorganic phosphates in solvent and water-borne paints: a synergism case", Applied Surface Science, Vol. 252 No. 5, pp. 1386-1397.

Brito-Rojas, A.D. Coutín-Correa, D.P. Rodríguez-Fuentes, G. and Pérez García, O. (2017), "Sedimentary zeolite deposits in Cuba", available at: www.iza-online.org/natural/Catalog/ Cuba.pdf

Calabrese, L. (2018), "Anticorrosion behavior of zeolite coatings obtained by in situ crystallization: a critical review", Materials, Vol. 12 No. 1, p. 59.

D’alessandro, O., Selmi, G.J., Di Sarli, A.R., Romagnoli, R. and Deyá, C. (2019), "Accelerated tests, a necessary complement of electrochemical assays to evaluate anticorrosive coatings", fournal of Applied Electrochemistry, Vol. 49 No. 8, pp. 811-822.

Devaki, H. and Gomathi Priya, P. (2016), "Corrosion studies using zeolite synthesized from fly ash", Indian fournal of Science and Technology, Vol. 9 No. 20, pp. 1-10.

Deyá, M.C., Del Amo, B., Spinelli, E. and Romagnoli, R. (2013), "The assessment of a smart anticorrosive coating by the electrochemical noise technique", Progress in Organic Coatings, Vol. 76 No. 4, pp. 525-532.

Dias, S. A S., Lamaka, S.V., Diamantino, T.C. and Ferreira, M.G.S. (2014), "Synergistic protection against corrosion of AA2024-T3 by Sol-gel coating modified with La and MoEnriched zeolites", Fournal of the Electrochemical Society, Vol. 161 No. 4, pp. C215-C222.

Dias, S. A S., Lamaka, S.V., Nogueira, C.A., Diamantino, T. C. and Ferreira, M.G.S. (2012), "Sol-gel coatings modified with zeolite fillers for active corrosion protection of AA2024", Corrosion Science, Vol. 62, pp. 153-162.

Ferrer, E.L., Rollon, A.P., Mendoza, H.D., Lafont, U. and Garcia, S.J. (2014), "Double- doped zeolites for corrosion protection of aluminium alloys", Microporous and Mesoporous Materials, Vol. 188, pp. 8-15.

Hernández, M., Genescá, J., Uruchurtu, J. and Barba, A. (2009), "Correlation between electrochemical impedance and noise measurements of waterborne coatings", Corrosion Science, Vol. 51 No. 3, pp. 499-510.

Iyigundogdu, Z., Demircì, S., Bac, N. and Şahİn, F. (2014), "Development of durable antimicrobial surfaces containing silver- and zinc-ion-exchanged zeolites", Turkish fournal of Biology, Vol. 38 No. 3, pp. 420-427.

Jamali, S.S. and Mills, D.J. (2016), "A critical review of electrochemical noise measurement as a tool for evaluation of organic coatings", Progress in Organic Coatings, Vol. 95, pp. 26-37.

Kabwadza-Corner, P., Munthali, M.W., Johan, E. and Matsue, N. (2014), "Comparative study of copper adsorptivity and selectivity toward zeolites", American fournal of Analytical Chemistry, Vol. 05 No. 07, pp. 395-405.
Klein, C. and Philpotts, A. (2017), "Metamorphic rocks", in Klein, C. and Philpotts, A. (Eds), Earth Materials: Introduction to Mineralogy and Petrology, Cambridge University Press. Cambridge.

Kozhevnikova, N.M. and Styazhkina, E.N. (2013), "Sorption of gadolinium (III) ions by a natural clinoptilolite-containing tuff", Open Fournal of Physical Chemistry, Vol. 03 No. 03, pp. 115-118.

Kustovska, A.D. (2018), "Adsorption of methanol and water vapor on modified forms of mordenite-clinoptilolite rock", Adsorption Science E Technology, Vol. 36 No. 3-4, pp. 927-935.

McCafferty, E., Bernett, M.K. and Murday, J.S. (1988), "An XPS study of passive filme formation on iron in chromate solutions", Corrosion Science, Vol. 28 No. 6, pp. 559-576.

Mansouri, N., Panahi, H.A., Rikhtegar, N. and Atabi, F. (2013), "Porosity, characterization and structural properties of natural zeolite - clinoptilolite - as a sorbent", Environment Protection Engineering, Vol. 39 No. 1, pp. 139-152.

Ming, D.W. and Dixon, J.B. (1987), "Quantitative determination of clinoptilolite in soils by a cation-exchange capacity method", Clays and Clay Minerals, Vol. 35 No. 6, pp. 463-468.

Munthali, W.M., Elsheikh, A.M., Johan, E. and Matsue, N. (2014), "Proton adsorption selectivity of zeolites in aqueous media: effect of Si/Al ratio of zeolites", Molecules, Vol. 19 No. 12, pp. 20468-20481.

Nasir Khan, M. and Mohammad, F. (2014), "Eutrhophication: Challenges and solutions", in Ansari, A.A. and Singh Gill, S. (Eds), Eutrophication: Causes, Consequences and Control, Springer. New York, NY.

Orman, S. (1965), "Economic aspects of corrosion", in Shreir, L.L. (Ed.), Corrosion, Newnes-Butterworths London.

Rojas-Pavón, C.X., Olguín, M.T., Jiménez-Cedillo, M.J. and Maubert, A.M. (2015), "Sorption properties of modified clinoptilolite and mordenite rich tuffs for manganese removal from aqueous systems", Research and Reviews in Materials Science and Chemistry, Vol. 5 No. 1, pp. 29-61.

Roselli, S., Deyá, C., Revuelta, M., Di Sarli Alejandro, R. and Romagnoli, R. (2018), "Zeolites as reservoirs for Ce(III) as passivating ions in anticorrosion paints", Corrosion Reviews, Vol. 36 No. 3, p. 305.

Roselli, S., Bellotti, N., Deyá, C., Revuelta, M., Del Amo, B. and Romagnoli, R. (2014), "Lanthanumexchanged zeolite and clay as anticorrosive pigments for galvanized steel", Fournal of Rare Earths, Vol. 32 No. 4, pp. 352-359.

Saxena, A., Sharma, V., Thakur, K.K. and Bhardwaj, N. (2020), "Electrochemical studies and the surface examination of low carbon steel by applying the extract of citrus sinensis", fournal of Bio- and Tribo-Corrosion, Vol. 6 No. 2 .

Selvam, T., Schwieger, W. and Dathe, W. (2018), "Natural cuban zeolites for medical use and their 
histamine binding capacity", Clay Minerals, Vol. 49 No. 4, pp. 501-512.

Shaw, R. and Tiwari, S. (2016), "Fly ash based zeolitic pigments for application in anticorrosive paints", $A I P$ Conference Proceedings, Vol. 1724 No. 1.

Stashkiv, O., Vasylechko, V., Gryshchouk, G. and Patsay, I. (2019), "Solid phase extraction of trace amounts of praseodymium using transcarpathian clinoptilolite", Colloids and Interfaces, Vol. 3 No. 1, p. 27.

\section{Further reading}

ALKIPOL (2020), “ALKIPOL $® 434 / 50$ data sheet”, available at: www.polidur.com.ar/info/ht/alquidicas/434$50 \% 20$ A.pdf

\section{Corresponding author}

Oriana D'Alessandro can be contacted at: o.dalessandro@ cidepint.ing.unlp.edu.ar

For instructions on how to order reprints of this article, please visit our website:

www.emeraldgrouppublishing.com/licensing/reprints.htm

Or contact us for further details: permissions@emeraldinsight.com 